

\section{NOAA TECHNICAL REPORTS}

\section{National Marine Fisheries Service, Circulars}

The major responsibilities of the National Marine Fisheries Service (NMFS) are to monitor and assess the abundance and geographic distribution of fishery resources, to understand and predict fluctuations in the quantity and distribution of these resources, and to establish levels for optimum use of the resources. NMFS is also charged with the development and implementation of policies for managing national fishing grounds, development and enforcement of domestic fisheries regulations, surveillance of foreign fishing off United States coastal waters, and the development and enforcement of international fishery agreements and policies. NMFS also assists the fishing industry through marketing service and economic analysis programs, and mortgage insurance and ressel construction subsidies. It collects, analyses, and publishes statistics on various phases of the industry.

The NOAA Technical Report NMFS CIRC series continues a series that has been in existence since 1941 . The Circulars are technical publications of general interest intended to aid conservation and management. Publications that review in considerable detail and at a high technical level certain broad areas of research appear in this series. Technical papers originating in economics studies and from management investigations appear in the Circular series.

NOAA Technical Reports NMFS CIRC are available free in limited numbers to governmental agencies, both Federal and State. They are also available in exchange for other scientific and technical publications in the marine sciences. Individual copies may be obtained (unless otherwise noted) from NOAA Publications Section, Rockville, MId. 20852. Recent Circulars are:

315. Synopsis of biological data on the chum salmon, Oncorhynchus keta (Walbaum) 1792. By Richard G. Bakkala. March 1970 , iii +89 pp., 15 figs., 51 tables.

319. Bureau of Commercial Fisheries Great Lakes Fishery Laboratory, Ann Arbor, Michigan. By Bureau of Commercial Fisheries. March 1970, 8 pp., 7 figs.

330. EASTROPAC Atlas: Vols. 4, 2, Catalog No. I $49.4: 330 /$ (vol.) 11 vols. ( $\$ 4.75$ each). Available from the Superintendent of Documents, Washington, D.C. 20402.

331. Guidelines for the processing of hot-smoked chub. By H. L. Seagran, J. T. Graikoski, and J. A. Emerson. January 1970, iv + 23 pp., 8 figs., 2 tables.

332. Pacific hake. (12 articles by 20 authors.) March 1970, iii + 152 pp., 72 figs., 47 tables.

333. Recommended practices for vessel sanitation and fish handling. By Edgar W. Bowman and Alfred Larsen. March 1970, iv + 27 pp., 6 figs.

395. Progress report of the Bureau of Commercial Fisheries Center for Estuarine and Menhaden Research, Pesticide Field Station, Gulf Breeze, Fla., fiscal year 1969. By the Laboratory staff. August 1970, iii + 33 pp., 29 figs., 12 tables.

336. The northern fur seal. By Ralph C. Baker, Ford Wilke, and C. Howard Baltzo. April 1970, iii + 19 pp., 13 figs.

337. Program of Division of Economic Research, Bureau of Commerecial Fisheries, fiscal year 1969. By Division of Economic Research. April 1970, iii +29 pp., 12 figs., 7 tables.
338. Bureau of Commercial Fisheries Biological Laboratory, Auke Bay, Alaska. By Bureau of Commercial Fisheries. June 1970, 8 pp., 6 figs.

339. Salmon research at Ice Harbor Dam. By Wesley J. Ebel. April 1970, 6 pp., 4 figs.

340. Bureau of Commercial Fisheries Technological Laboratory, Gloucester, Massachusetts. By Bureau of Commercial Fisheries. June 1970, 8 pp., 8 figs.

341. Report of the Bureau of Commercial Fisheries Biological Laboratory, Beaufort, N.C., for the fiscal year ending June 30, 1968. By the Laboratory staff. August 1970, iii + 24 pp., 11 figs., 16 tables.

342. Report of the Bureau of Commercial Fisheries Biological Laboratory, St. Petersburg Beach, Florida, fiscal year 1969. By the Laboratory staff. August 1970, iii +22 pp., 20 figs., 8 tables.

343. Report of the Bureau of Commercial Fisheries Biological Laboratory, Galveston, Texas, fiscal year 1969. By the Laboratory staff. August 1970 , iii +39 pp., 28 figs., 9 tables.

344. Bureau of Commercial Fisheries Tropical Atlantic Biological Laboratory progress in research 1965-69, Miami, Florida. By Ann Weeks. October 1970 , iv + 65 pp., 53 figs.

346. Sportsman's guide to handling, smoking, and preserving Great Lakes coho salmon. By Shearon Dudley, J. T. Graikoski, H. L. Seagran, and Paul M. Earl. September 1970 , iii +28 pp., 15 figs.

347. Synopsis of biological data on Pacific ocean perch, Sebastodes alutus. By Richard L. Major and Herbert H. Shippen. December 1970, iii + 38 pp., 31 figs., 11 tables. 


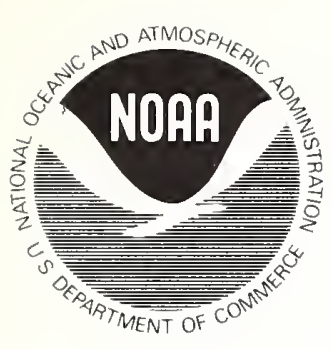

U.S. DEPARTMENT OF COMMERCE

Peter G. Peterson, Secretary

NATIONAL OCEANIC AND ATMOSPHERIC ADMINISTRATION

Robert M. White, Administrator

NATIONAL MARINE FISHERIES SERVICE

Philip M. Roedel, Director

\section{NOAA Technical Report NMFS CIRC-369}

\section{Field Guide to the Angelfishes (Pomacanthidae) in the Western Atlantic}

HENRY A. FEDDERN

\section{SEATTLE, WA}

November 1972

For sale by the Superintendent of Documents, U.S. Government Printing Office Washington, D.C. 20402 - Price 25 cents 
The National Marine Fisheries Service (NMFS) does not approve, recommend or endorse any proprietary product or proprietary material mentioned in this publication. No reference shall be made to NMFS, or to this publication furnished by NMFS, in any advertising or sales promotion which would indicate or imply that NMFS approves, recommends or endorses any proprietary product or proprietary material mentioned herein, or which has as its purpose an intent to cause directly or indirectly the advertised product to be used or purchased because of this NMFS publication. 


\section{CONTENTS}

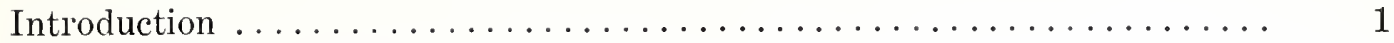

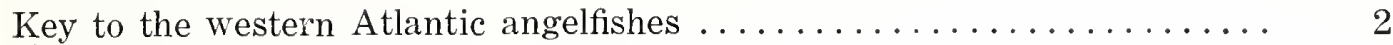

Pomacanthus arcuatus (Linnaeus, 1758) ................ 7

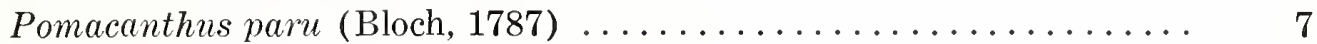

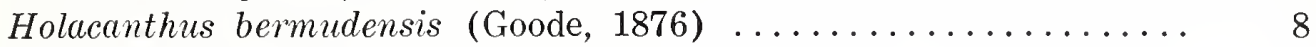

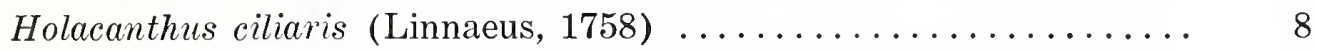

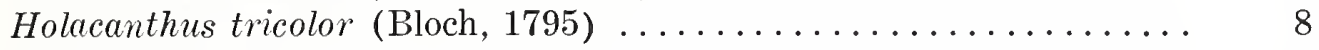

Centropyge argi Woods and Kanazawa, $1951 \ldots \ldots \ldots \ldots \ldots \ldots \ldots . \ldots$

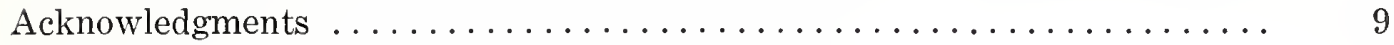

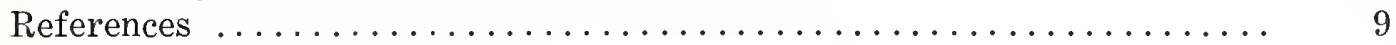

Figures

1. Pomacanthus arcuatus, juvenile, $48.3 \mathrm{~mm}$ SL (2 inches TL) ........

2. Pomacanthus arcuatus, subadult, $88.0 \mathrm{~mm}$ SL (4 inches TL) ....... 2

3. Pomacanthus arcuatus, gray angelfish, adult, $215 \mathrm{~mm}$ SL (9 inches TL) 2

4. Pomacanthus paru, juvenile, $40.5 \mathrm{~mm}$ SL (2 inches TL) ........ 3

5. Pomacanthus paru, subadult, $105 \mathrm{~mm}$ SL (4 inches TL) ......... 3

6. Pomacanthus paru, French angelfish, adult, $205 \mathrm{~mm}$ SL (9 inches TL) 3

7. Holacanthus bermudensis, juvenile, $41.0 \mathrm{~mm}$ SL (2 inches TL) ..... 4

8. Holacanthus bermudensis, subadult, $101 \mathrm{~mm}$ SL (4 inches TL) ..... 4

9. Holacanthus bermudensis, blue angelfish, adult, $208 \mathrm{~mm} \mathrm{SL}$

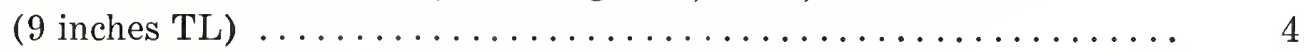

10. Holacanthus ciliaris, juvenile, $43.2 \mathrm{~mm} \mathrm{SL}(2$ inches TL) ........ 5

11. Holacanthus ciliaris, subadult, $84.4 \mathrm{~mm} \mathrm{SL} \mathrm{(4} \mathrm{inches} \mathrm{TL)} \mathrm{........} 5$

12. Holacanthus ciliaris, queen angelfish, adult, $201 \mathrm{~mm}$ SL (9 inches TL) 5

13. Holacanthus tricolor, juvenile, $26.8 \mathrm{~mm} \mathrm{SL} \mathrm{(11/2} \mathrm{inches} \mathrm{TL)} \mathrm{......} 6$

14. Holacanthus tricolor, subadult, $77.3 \mathrm{~mm}$ SL (31/2 inches TL) ..... 6

15. Holacanthus tricolor, rock beauty, adult, $145 \mathrm{~mm} \mathrm{SL} \mathrm{(6} \mathrm{inches} \mathrm{TL)} \mathrm{.} 6$

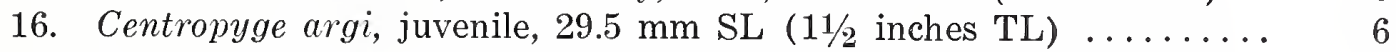

17. Centropyge argi, pigmy angelfish, adult, $65.3 \mathrm{~mm}$ SL (3 inches TL) . $\quad 7$ 
Digitized by the Internet Archive in 2013 


\title{
FIELD GUIDE TO THE ANGELFISHES (POMACANTHIDAE) IN THE WESTERN ATLANTIC'
}

\author{
By \\ HENRY A. FEDDERN, Director, Marine Laboratory \\ Precision Valve Corporation \\ 8737 SW 132 Street \\ Miami, Florida 33156
}

\begin{abstract}
A key illustrated by photographs and brief descriptions is presented to aid in identifying the six species of angelfishes, family Pomacanthidae, found in the western Atlantic.
\end{abstract}

\section{INTRODUCTION}

Fishes of the family Pomacanthidae ${ }^{2}$ are distinguished from those of the Chaetodontidae by the presence in the former of a large posteriorly pointing spine at the angle of the preoperculum. Worldwide, there are seven recognized genera, with three (Pomacanthus, Holacanthus, and Centropyge) occurring in the western Atlantic.

${ }^{1}$ Contribution No. 215, National Marine Fisheries Service, Southeast Fisheries Center, Miami, Fl. 33149 and Contribution No. 1542, Rosenstiel School of Marine and Atmospheric Science, University of Miami, Miami, Fl. 33149.

2 Angelfishes have been separated under the name Pomacanthidae from the butterflyfishes (Chaetodontidae) by Burgess, W. (in press) on the basis of osteological and other characters.
In this area, the genera are represented by six species. These have been difficult to identify because of nomenclatorial changes and because of color changes from juvenile to adult.

The juveniles of these species are of commercial importance in the marine aquarium fish hobby, and the adults are the basis of a fishery in some parts of the Caribbean and the Antilles. The angelfishes comprise the most important group of fishes using live sponge as a source of food.

An illustrated key is given for the identification of the juvenile, subadult, and adult stages of the western Atlantic species of angelfishes. Brief descriptions, common names, habitat, and distributions are also given for each species. 


\section{KEY TO THE WESTERN ATLANTIC ANGELFISHES}

A. Dorsal spines 8 to $10 \ldots \ldots \ldots \ldots$

AA. Dorsal spines 13 to $15 \ldots \ldots \ldots$. C

B. Dorsal spines 9 (rarely 8 or 10 ). JUVENILE (less than 3 inches long) black with vertical yellow bars; the first bar (extending along the anterior edge of the head and between the eyes) extending across second bar (encircling the mouth) onto lower jaw; caudal fin truncate, with yellow bar on base, black oval in middle, and border transparent; blue areas present on anal and ventral fins. SUBADULT individuals gray, each scale with darker spot, and with the yellow bars less distinct. ADULTS brownish-gray, with black spot on each large scale of body; inner side of pectoral fin pale yellow; jaws white .....

gray angelfish. Pomacanthus arcuatus

(Fig. 1-3).

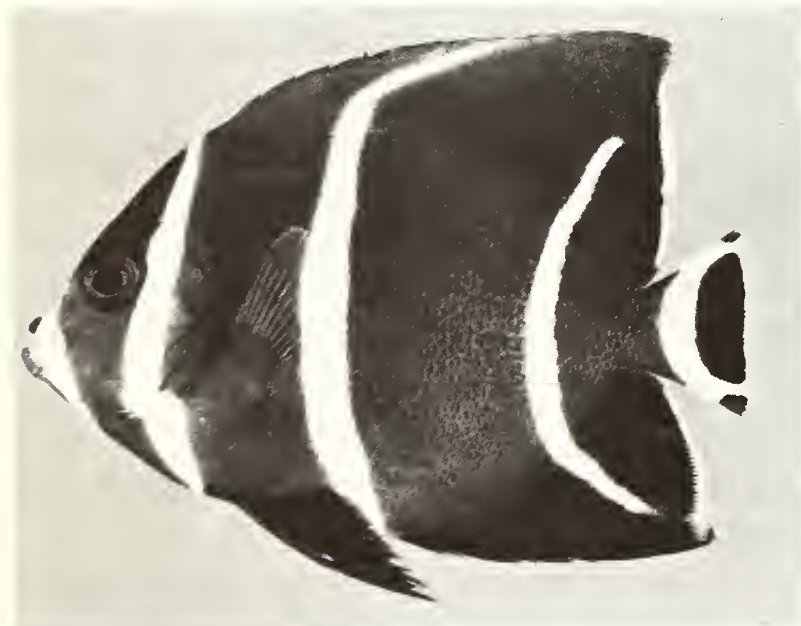

Figure 1-.Pomacanthus arcuatus, juvenile, $48.3 \mathrm{~mm}$ SL (2 inches TL).

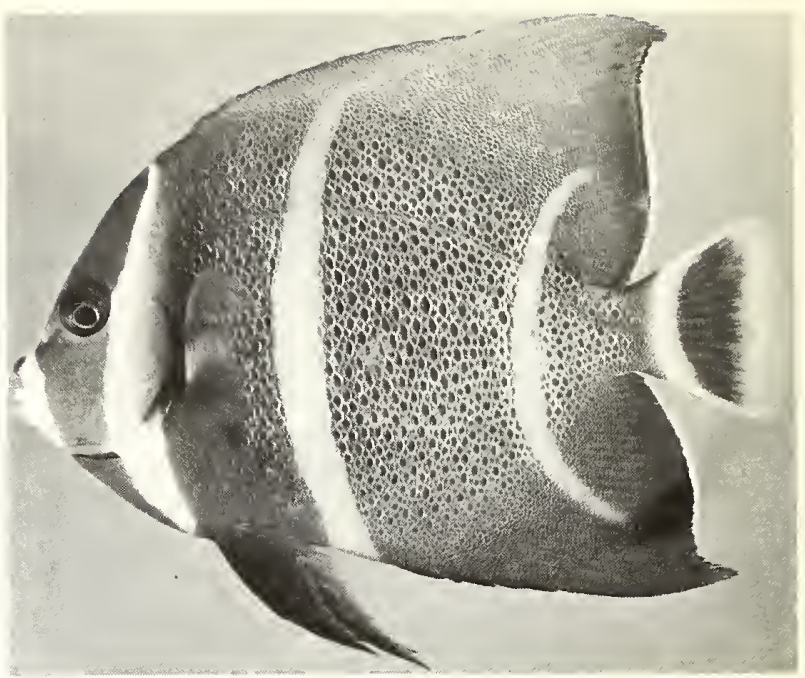

Figure 2.-Pomacanthus arcuatus, subadult, $88.0 \mathrm{~mm}$ SL (4 inches TL).

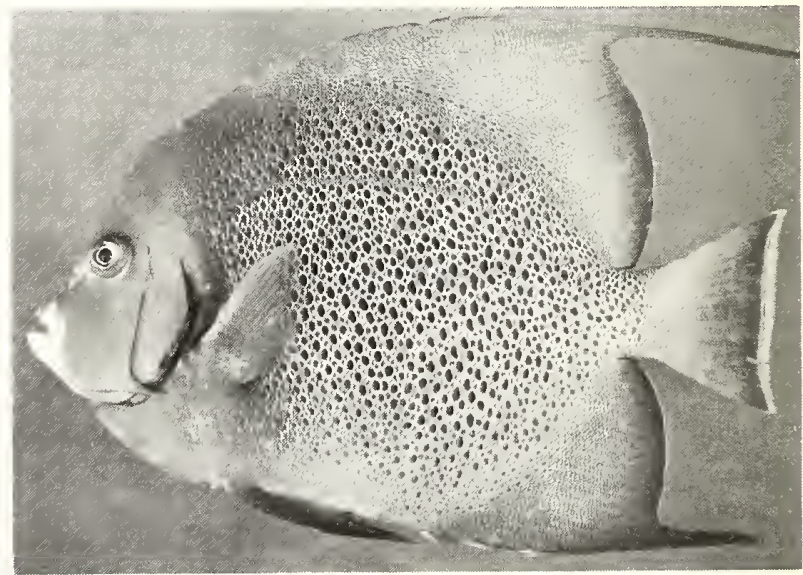

Figure 3.-Pomacanthus arcuatus, gray angelfish, adult, $215 \mathrm{~mm}$ SL (9 inches TL). 
BB. Dorsal spines 10 (rarely 9). JUVENILE (less than 3 inches long) black with vertical yellow bars; the first bar (extending along the anterior edge of the head and between the eyes) extending downward only to second bar (encircling the mouth) and not crossing onto the jaws; caudal fin convex with narrow yellow stripe encircling elliptical black spot; blue areas present on the anal and ventral fins. SUBADULT individuals black, with several bars still present, but also with yellow crescents on large scales of body. ADULTS black with yellow crescents on the large scales; yellow stripe encircling eye and a yellow bar in front of pectoral fin;

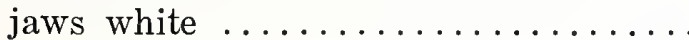

French angelfish.

Pomacanthus paru

(Fig. 4-6).

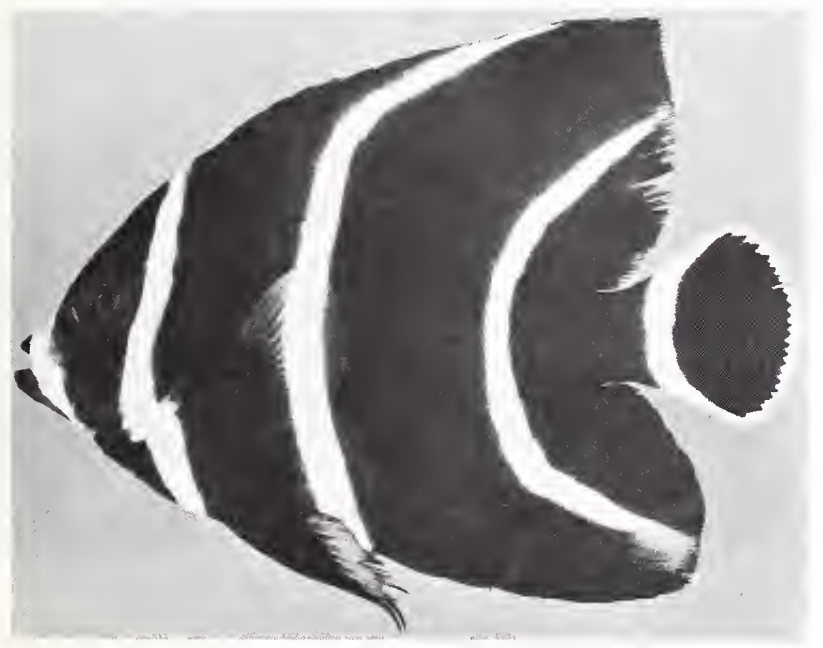

Figure 4.-Pomacanthus paru, juvenile, $40.5 \mathrm{~mm}$ SL ( 2 inches TL).

Figure 5.-Pomacanthus paru, subadult, $105 \mathrm{~mm}$ SL (4 inches TL).
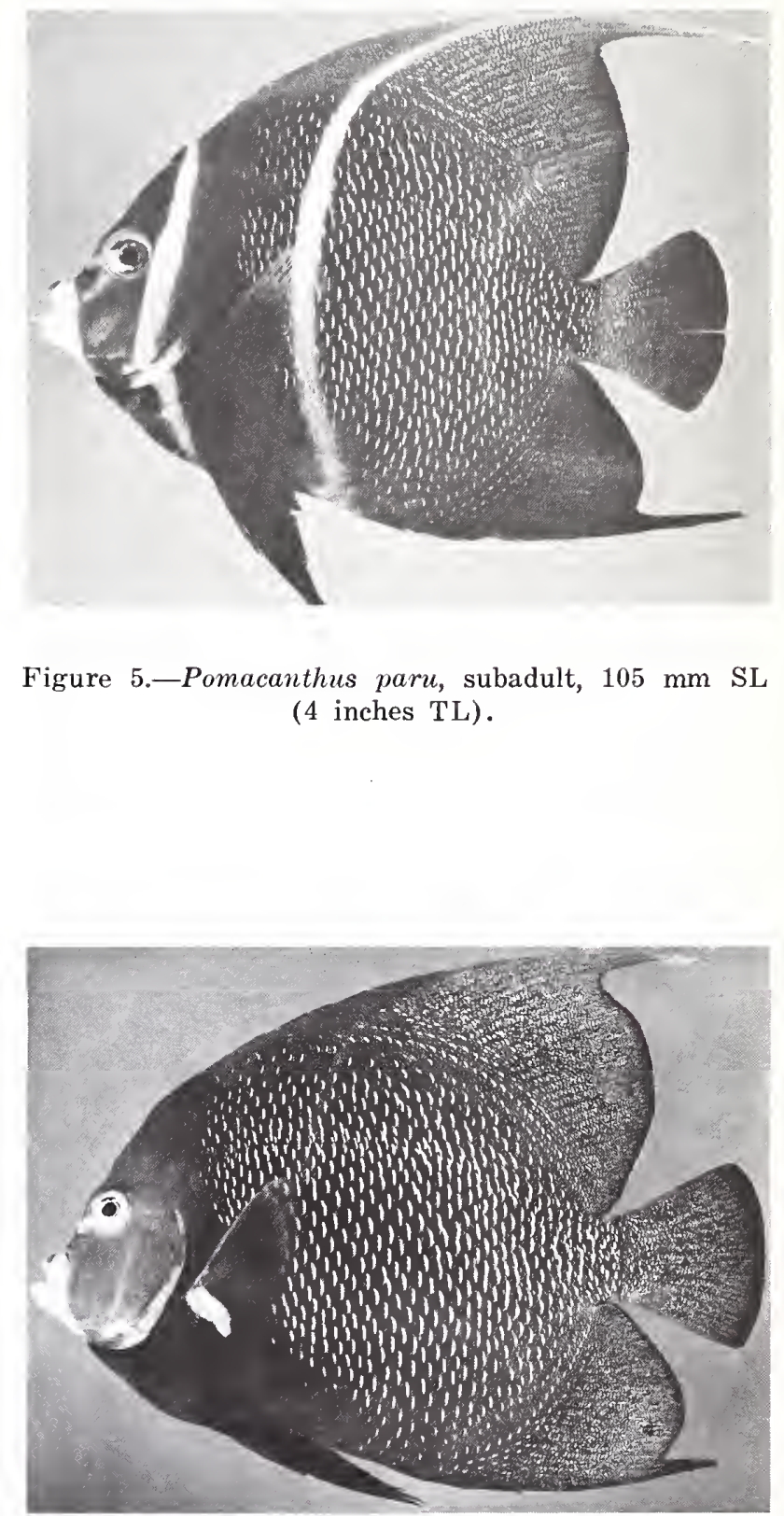

Figure 6.-Pomac inthus paru, French angelfish, adult, $205 \mathrm{~mm}$ SL (9 inches TL). 
C. Jureniles and subadults with bluishwhite bars on body; adults with no large black areas on body posterior to the pectoral fin ...................

CC. Jureniles, subadults, and adults with the body blackish or with a large black area posterior to the pectoral fin. No bars on the body ................

D. JUVENILE dark blue, with vertical bluish-white bars on head and body, and yellow-orange color on jaws, below eye, and on ventral and caudal fins; fourth major bluish-white bar (counting from front to rear) nearly straight. SUBADULT individuals with bars increasing in number, but then all fading; body becoming paler; posterior parts of dorsal and anal fins becoming yellow. ADULTS with bluish-whitish-brownish tone over head and body, and white edges present on the large scales of body; distal edge only of caudal fin yellow, the rest similar in color to that of body; blue extending into proximal half of pectoral fin; usually no black mark-

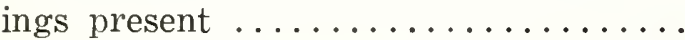

blue angelfish. Holacanthus bermudensis (Fig. 7-9).

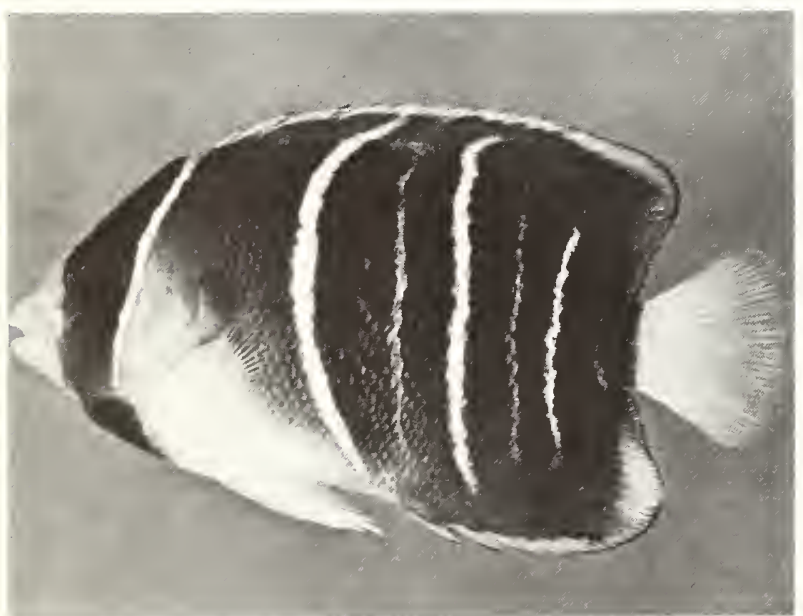

Figure 7.-Holacanthus bermudensis, juvenile, $41.0 \mathrm{~mm}$ SL (2 inches TL).

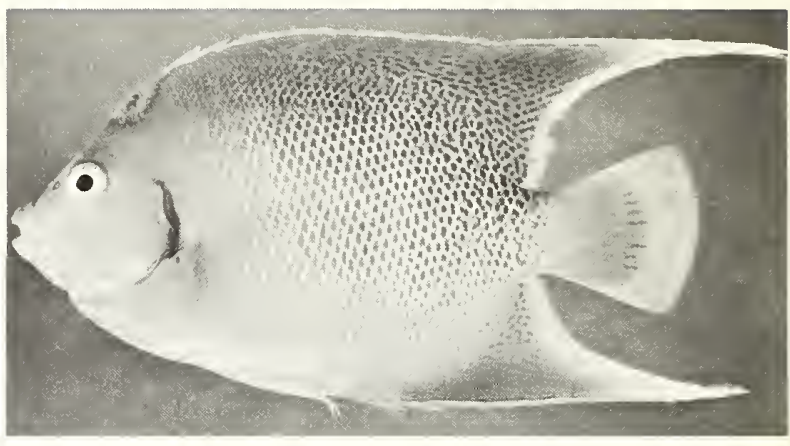

Figure 8.-Holacanthus bermudensis, subadult, $101 \mathrm{~mm}$ SL (4 inches TL).

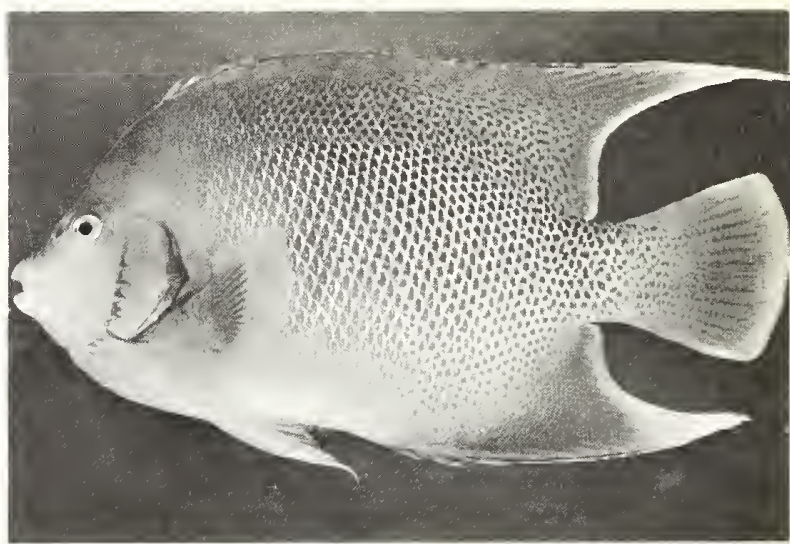

Figure 9.-Holacanthus bermudensis, blue angelfish, adult, $208 \mathrm{~mm}$ SL (9 inches TL). 
DD. JUVENILE (less than 2 inches long) dark blue, with vertical bluish-white bars on head and body, and yellow-orange on jaws, below eye, and on ventral and caudal fins; fourth bar (counting from front to rear) conspicuously curved. SUBADULT individuals with the bars fading and the body becoming paler with the adult pattern forming. ADULTS bluish to greenish on body, with orange triangles on large scales of body; large black spot speckled and encircled with blue present on nape, with orange streak immediately posterior to it; a large black spot with a blue bar present at base of pectoral fin; black blotches present on last rays of dorsal and anal fins; caudal fin entirely yellow

queen angelfish.

Holacanthus ciliaris ${ }^{3}$

(Fig. 10-12).

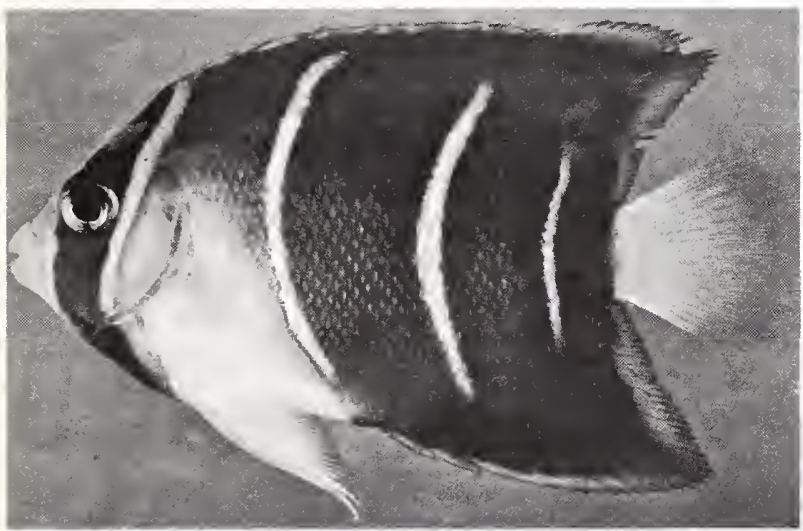

Figure 10.-Holacanthus ciliaris, juvenile, $43.2 \mathrm{~mm}$ SL ( 2 inches TL).

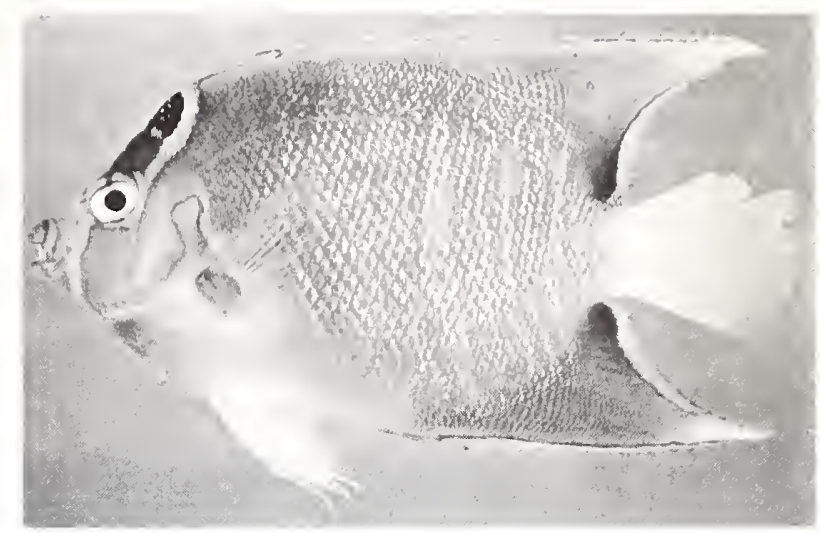

Figure 11.-Holacanthus ciliaris, subadult, $84.4 \mathrm{~mm}$ SL (4 inches TL).

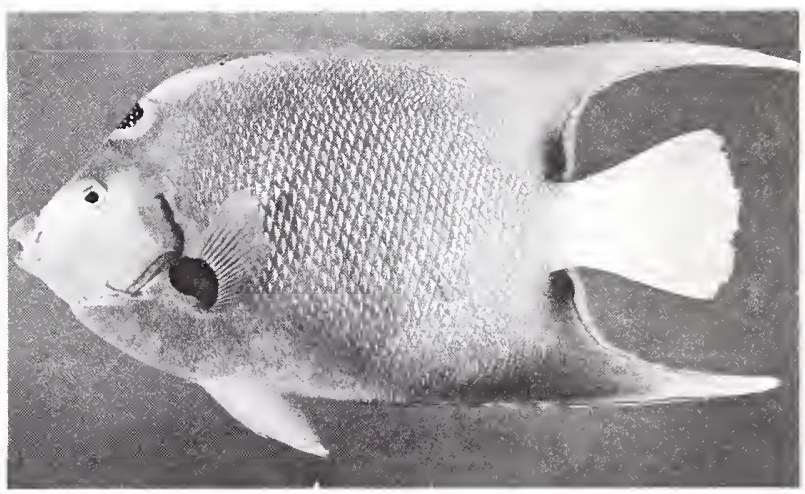

Figure 12.-Holacanthus ciliaris, queen angelfish, adult, $201 \mathrm{~mm}$ SL (9 inches TL).
${ }^{3}$ Occasionally, angelfishes are found that display color patterns intermediate between those of the queen and blue angelfishes. These individuals are hybrids between the two species. (See Feddern, H. A., 1968a and b, for a more complete analysis of the status of these hybrids.) 
E. JUVENILE (less than 1.5 inches long) bright yellow, with black spot (encircled with blue) on upper side of body. SUBADULT individuals with black area expanding across blue circle and over the central portion of the body. ADULTS black over the central and rear parts of body and on dorsal and anal fins; head, forepart of body, and caudal, pectoral, and pelvic fins yellow; red on edges of dorsal and anal fins .........

rock beauty. Holacanthus tricolor (Fig. 13-15).

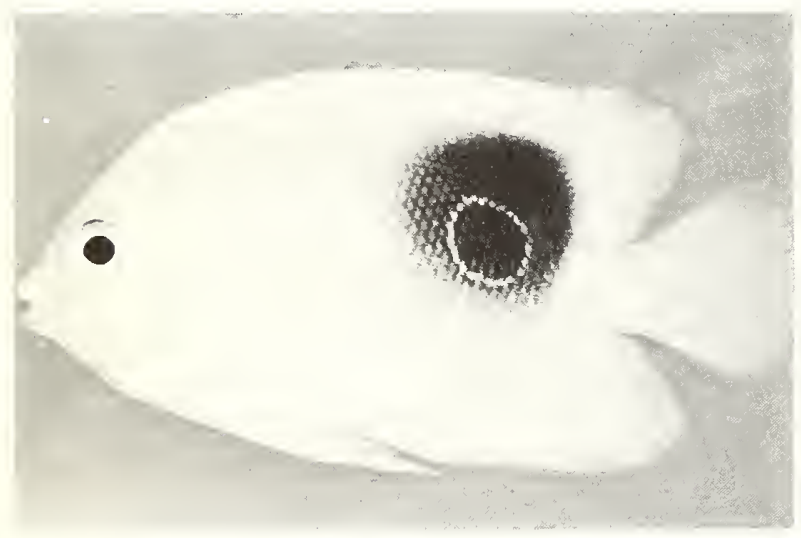

Figure 13.-Holacanthus tricolor, juvenile, $26.8 \mathrm{~mm}$ SL (1 1/2 inches TL).

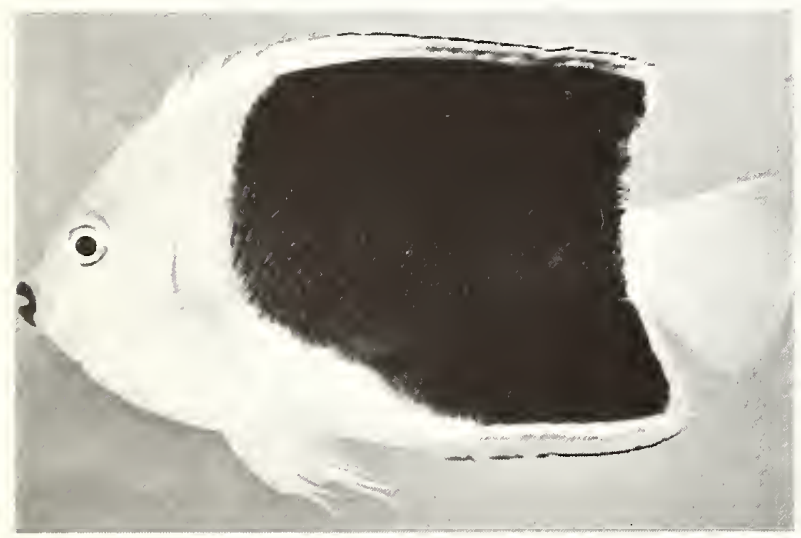

Figure 14.-Holacanthus tricolor, subadult, $77.3 \mathrm{~mm}$ SL $(31 / 2$ inches TL).

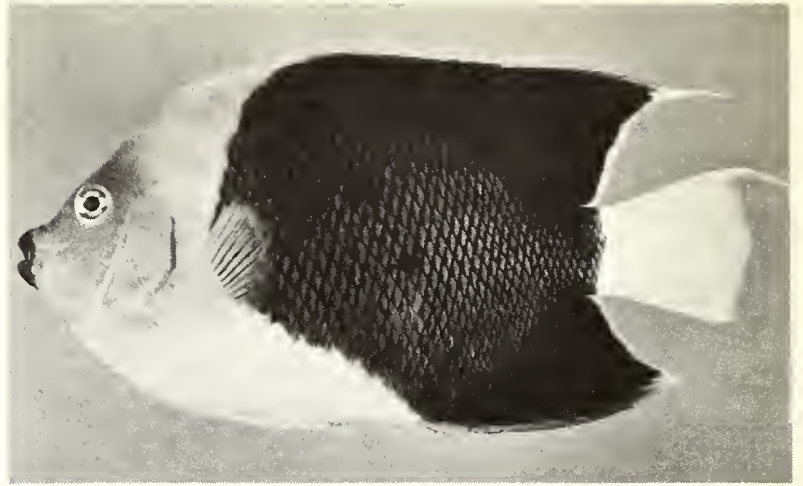

Figure 15.-Holacanthus tricolor, rock beauty, adult, $145 \mathrm{~mm}$ SL (6 inches TL)

EE. Body of juvenile and adult overall bluish-black, with orange on head and breast. Narrow blue stripe encircling eye, and other blue stripes outlining the head spines. Individuals usually less than 3 inches long ..............

pigmy angelfish.

Centropyge argi

(Fig. 16-17).

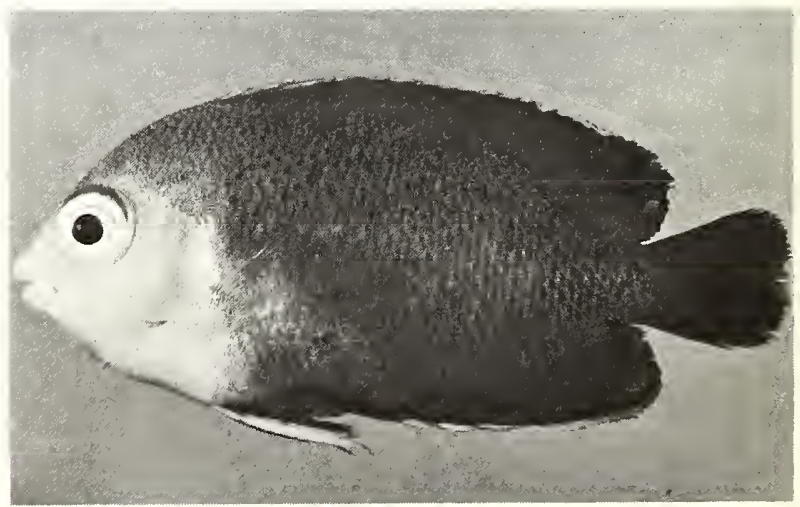

Figure 16.-Centropyge argi, juvenile, $29.5 \mathrm{~mm}$ SL (11/2 inches TL). 
Pomacanthus arcuatus (Linnaeus, 1758)

gray angelfish

Figures 1-3

Characterized by 8 to 10 spines in the dorsal fin (usually 9); adults with brownish-gray coloration and a black spot on large body scales. Dorsal soft rays 29-33 (usually 30-32). Anal fin with 3 spines and 17-20 soft rays (usually 18-19). Pectoral fin with 1 spine and $18-19$ soft rays. Lateral-line scale pores 43-50 (usually 4549). Gill rakers 16-19 (usually 17-18). Maximum size: from literature records, $2 \mathrm{ft}, 6.5 \mathrm{lb}$.; from personal collections, $315 \mathrm{~mm}$ Standard Length [SL] (15 inches Total Length [TL]), $1,852 \mathrm{~g}$.

This species has often been referred to as Pomacanthus aureus (Bloch, 1787). Common names are black angelfish (also used for $P$. paru and Holacanthus tricolor in Bermuda), gray angelfish, chirivita, chivirita, chibirico, nortugais, mariposa, zwarte angel, tjamba, frade, paru-da-pedra, squaretail black angelfish, zwarte engel, and cachama blanca.

The gray angelfish is relatively common in its habitat near the bottom in sponge, coral and rocky areas from shore to the deepest part of the reef (in Florida). In British Guiana, the species has been found as deep as $198 \mathrm{ft}$. Juveniles are solitary; adults form large aggregations, small groups, and male-female pairs.

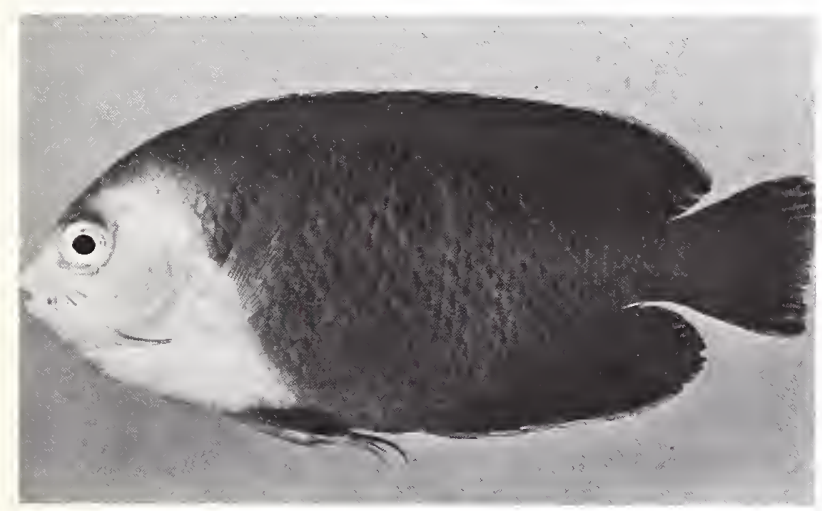

Figure 17.-Centropyge argi, pigmy angelfish, adult, $65.3 \mathrm{~mm}$ SL (3 inches TL).
The gray angelfish occurs in an area of the western Atlantic bounded by: northeast Florida, Bermuda, Bahamas, Turks Islands, Puerto Rico, Virgin Islands, Martinique, Grenadines, Trinidad, Salvador* (Brazil), British Guiana, Curaçao, Panama (Caribbean), Conzumel, Cuba, and the west coast of Florida. The species strays northward along the east coast of the United States to New Jersey.

\section{Pomacanthus paru (Bloch, 1787)}

\section{French angelfish}

Figures 4-6

Characterized by $9-10$ spines in the dorsal fin (usually 10); adults black with yellow crescents on large body scales. Dor'sal soft rays 27-31 (usually 29-30). Anal fin with 3 spines and 2124 soft rays (usually $22-23$ ). Pectoral fin with 1 spine and 17-19 soft rays (usually 18). Lateralline scale pores 40-48 (usually 46-47). Gill rakers 17-20 (usually 18). Maximum size: from literature records, 14 inches; from personal collections, $330 \mathrm{~mm}$ SL (16 inches TL), 1,772 g.

This species has also been called black angelfish. Other common names are tjamba pretoe, chivirita, chirivita, chivirica, chibirico, indianfish, flatfish, paru, roundtail black angelfish, and cachama negra.

The species is common but scattered throughout its habitat. It is found near the bottom in areas of sponge, coral, and rock and occurs from shore to the deepest part of the reef (in Florida). Off Colombia, the species has been found at a depth of $228 \mathrm{ft}$. Juveniles are solitary. Adults usually form pairs but may also be seen in small groups.

The French angelfish occurs in an area of the western Atlantic bounded by: northeast Florida, Bermuda, Bahamas, Turks Islands, Virgin Islands, St. Martin, Grenadines, Natal (Brazil), Ascension Island, Colombia, Panama (Caribbean), Costa Rica (Caribbean), Texas, and Fort Walton Beach (Florida). The species may stray northward along the east coast of the United States to New Jersey.

\footnotetext{
4 Also known as Bahia.
} 
Holacanthus bermudensis (Goode, 1876)

blue angelfish

$$
\text { Figures 7-9 }
$$

Characterized by 13-15 spines in the dorsal fin (usually 14); adults with white edges on large body scales, only the distal margin of the caudal fin yellow, and lacking a large spot on the nape. Dorsal soft rays 18-21 (usually 19). Anal fin with 3 (rarely 4 ) spines and $18-20$ soft rays (usually 19). Pectoral fin with 1 spine and 16-20 soft rays (usually 18). Lateral-line scale pores 41-48 (usually 45). Gill rakers 18-22 (usually 19-20). Maximum size: from literature records, 18 inches, $6 \mathrm{lb}$; f from personal collections, $340 \mathrm{~mm}$ SL (16 inches TL), 1,964 g.

Other common names are common angelfish and spotted angelfish.

The blue angelfish is common in its habitat near the bottom in areas of sponge, coral, and rock. Off Florida, it occurs from shore to beyond the deepest portion of the reef. Off South Carolina, the species has been taken in a depth of $252 \mathrm{ft}$. Juveniles are solitary. Adults form aggregations of small to large size and pairs. Hybrids occur between this species and Holacanthus ciliaris.

The blue angelfish occurs in essentially a linear band along the eastern coast of the Americas, extending from Bermuda, South Carolina, Atlantic and Gulf sides of Florida to Texas and Alacranes (Yucatan). The species is rare but known to occur in the Bahamas and at St. Lucia, West Indies (Fowler, 1915).

\section{Holacanthus ciliaris (Linnaeus, 1758)}

\author{
queen angelfish
}

\section{Figures 10-12}

Characterized by $13-15$ spines in the dorsal fin (usually 14); adults with a black spot circled with blue on the nape, the caudal fin entirely yellow, and orange triangles on the large body scales. Dorsal soft rays 19-21 (usually 20). Anal fin with three spines and 19-20 soft rays. Pectoral fin with 1 spine and 16-19 soft rays (usually 18). Lateral-line scale pores 40-46 (usually 44-45). Gill rakers 18-22 (usually 1920). Maximum size: from literature records,
24 inches; from personal collections, $244 \mathrm{~mm} \mathrm{SL}$ (12 inches TL), $741 \mathrm{~g}$.

Other common names for this species are isabelita, rey de tjamba, yellow angel, golden angel, blue angel, patele, palometa, cachama de piedra, and marguerite.

The queen angelfish is fairly common in its habitat near the bottom in areas of sponge, coral, and rock. It occurs from shore to the deepest portion of the reef (in Florida). Juveniles are solitary. Adults usually form pairs. Hybrids occur between this species and Holacanthus bermudensis. ${ }^{5}$

The queen angelfish occurs in an area of the western Atlantic bounded by: northeast Florida, Bermuda, Bahamas, Turks Islands, Haiti, Puerto Rico, Virgin Islands, Barbados, Trinidad, Salvador $^{6}$ (Brazil), Bonaire, Panama (Caribbean), Nicaragua, Yucatan (Mexico), and Panama City (Florida).

\section{Holacanthus tricolor (Bloch, 1795) \\ rock beauty \\ Figures 13-15}

Characterized by $13-15$ spines in the dorsal fin (usually 14); adults black over most of the body with yellow caudal fin. Dorsal soft rays 17-19 (usually 17-18). Anal fin with 3 spines and 1720 soft rays (usually 18). Pectoral fin with 1 spine and 16-17 soft rays (usually 16). Lateralline scale pores $42-44$. Gill rakers 16-20 (usually 18). Maximum size: from literature records, 12 inches; from personal collections, $174 \mathrm{~mm} \mathrm{SL}$ (9 inches TL), $276 \mathrm{~g}$.

Other common names for this species are black angelfish (in Bermuda), tjamba, swede, catalineta, vaqueta de dos colores, banana kojo, soldado, ladronchi, cachama medio luteo, and marguerite.

The rock beauty is common in its habitat near the bottom in coral and rock areas. In Florida, the species is restricted to the offshore reefs, down to the limit of coral growth, whereas in the Bahamas individuals commonly occur along

\footnotetext{
${ }^{5}$ See footnote 3, p. 5 .

See footnote 4, p. 7 .
} 
shore also. Both juveniles and adults are usually solitary but are sometimes seen in small groups.

The rock beauty occurs in an area of the western Atlantic bounded by: Cumberland Island (Georgia), Bermuda, Bahamas, Turks Islands, Hispaniola, Puerto Rico, Virgin Islands, Guadeloupe, Barbados, Trinidad, Rio de Janeiro (Brazil), Salvador ${ }^{7}$ (Brazil), Natal (Brazil), British Guiana, Curaçao, Cuba, and Tortugas (Florida).

\section{Centropyge argi Woods and Kanazawa, 1951}

\author{
pigmy angelfish
}

Figures 16-17

Characterized by 14 spines in the dorsal fin (rarely 15); adults with the caudal fin and most of the body a bluish-black. Dorsal soft rays 1517 (usually 16). Anal fin with 3 spines and 16-17 soft rays. Pectoral fin with 1 spine and 15-16 soft rays. Lateral-line scale pores $36-42$ (usually 38). Gill rakers 21-24 (usually 22-23). Maximum size: from literature records, $53.5 \mathrm{~mm}$ SL; from personal collections, $62.1 \mathrm{~mm} \mathrm{SL} \mathrm{(3.5}$ inches TL), $14.5 \mathrm{~g}$.

Other common names for this species are velvet angelfish and cherubfish.

The pigmy angelfish is rare in shallow waters but is abundant in certain areas in deeper waters off southeast Florida and the Bahamas, in areas of coral and rock. In Martinique, the species has been found at a depth of $252 \mathrm{ft}$. Both the juveniles and adults occur singly or in small groups.

The pigmy angelfish at present is known to occur in an area of the western Atlantic bounded by: West Palm Beach (Florida), Bermuda, Bahamas, Dominican Republic, Virgin Islands, Martinique, Curaçao, Colombia, Yucatan, and Florida Keys.

\section{ACKNOWLEDGMENTS}

I would like to thank Dr. C. Richard Robins and Mr. Frederick Berry for their help in making available the fish collections of the Rosenstiel School of Marine and Atmospheric Science and

\footnotetext{
7 Sre footnote 4, p. 7 .
}

the Tropical Atlantic Biological Laboratory, respectively. They also helped to review the manuscript and make suggestions.

Mr. George C. Miller and Dr. Robert V. Miller of the Tropical Atlantic Biological Laboratory helped orient my thoughts on the relationships among the species, and the former aided in the final preparation of this manuscript which has been abstracted from a portion of my doctoral dissertation at the Rosenstiel School of Marine and Atmospheric Science, Miami, Florida.

\section{REFERENCES}

BOHLKE, J. E., and C. C. G. Chaplin.

1968. Fishes of the Bahamas and adjacent tropical waters. Livingston Publ. Co., Wynnewood, Pa., 771 p., 36 pls., many illus.

An excellent general account of the fishes found in the region.

FEDDERN, H. A.

1968a. Hybridization between the western Atlantic angelfishes Holacanthus isabelita and $H$. ciliaris. Bull. Mar. Sci., 18:351-382, 15 figs., 6 tables.

An analysis of hybridization and description of hybrids between the blue and queen angelfishes in Florida.

1968b. Systematics and ecology of western Atlantic angelfishes, family Chaetodontidae, with an analysis of hybridization in Holacanthus. Dissertation, University of Miami, Coral Gables, Fl., 211 p., 46 figs., 35 tables.

This dissertation is in three sections: a systematics section (from which this "Circular" is abstracted) with color photographs to illustrate juvenile, subadult, and adult of each species; a hybridization section, dealing with hybridization between the blue and queen angelfishes; and a food section, that analyzes the food and feeding of these angelfishes from four habitats in southern Florida.

FOWLER, H. W.

1915. The fishes of Trinidad, Grenada, and St. Lucia, British West Indies. Proc. Acad. Nat. Sci. Phila., 67:520-546, 4 figs.

FRASER-BRUNNER, A.

1933. A revision of the chaetodont fishes of the subfamily Pomacanthinae. Proc. Zool. Soc. Lond. 1933: 543-599, 29 text-figs., 1 pl.

A worldwide treatment of angelfishes, from preserved specimens. The species are described mainly from adults; few juveniles are shown.

HERALD, E. S.

1961. Living fishes of the world. Doubleday and Co., Inc., Garden City, N.Y., 304 p., 145 pls.

A general account of the major groups of fishes on a worldwide basis. 
LIMBAUGH, C.

1961. Cleaning symbiosis. Sci. Am., 205:42-49, illus.

Describes parasite-picking behavior of a number of the southern Florida marine fish and shrimp, including the French angelfish.

LONGLEY, W. H., and S. F. HILDEBRAND.

1941. Systematic catalogue of the fishes of Tortugas, Florida, with observations on color, habits and local distribution. Pap. Tortugas Lab., 34.
Carnegie Inst. Wash. Publ. 535, 331 p., 34 pls. A systematic account of the fishes present at the Dry Tortugas, including notes on behavior and coloration.

STRAUGHAN, R. P. L.

1964. The salt water aquarium in the home. A. S. Barnes and Co., New York, 304 p., 153 figs.

General information on maintaining marine fishes in home aquaria, with information on angelfishes scattered throughout the book. The names used are sometimes incorrect. 


349. Use of abstracts and summaries as communication devices in technical articles. By F. Bruce Sanford. February 1971, iii +11 pp., 1 fig.

350. Research in fiscal year 1969 at the Bureau of - Commercial Fisheries Biological Laboratory, Beaufort, N.C. By the Laboratory staff. November 1970, ii + 49 pp., 21 figs., 17 tables.

351. Bureau of Commercial Fisheries Exploratory Fishing and Gear Research Base, Pascagoula, Mississippi, July 1, 1967 to June 30, 1969. By Harvey R. Bullis, Jr., and John R. Thompson. November 1970 , iv +29 pp., 29 figs., 1 table.

352. Upstream passage of anadromous fish through navigation locks and use of the stream for spawning and nursery habitat, Cape Fear River, N.C., 1962-66. By Paul R. Nichols and Darrell E. Louder. October 1970 , iv +12 pp., 9 figs. 4 tables.

356. Floating laboratory for study of aquatic organisms and their environment. By George R. Snyder, Theodore H. Blahm, and Robert J. McConnell. May 1971, iii +16 pp., 11 figs.

361. Regional and other related aspects of shellfish consumption - some preliminary findings from the 1969 Consumer Panel Survey. By Morton M. Miller and Darrel A. Nash. June 1971, iv + 18 pp., 19 figs., 3 tables, 10 apps. 
UNITED STATES

DEPARTMENT OF COMMERCE

PENN STATE UNIVERSITY LIBRARIES

|| || || || |||||| || ||||| |||||

A000072018538

NATIONAL OCEANIC \& ATMOSPHERIC ADMINISTRATION NATIONAL MARINE FISHERIES SERVICE

OSTAGE AND FEES PAID

SCIENTIFIC PUBLICATIONS STAFF

BLDG. 67, NAVAL SUPPORT ACTIVITY

S. DEPARTMENT OF COMMERCE

SEATIE, WASHINGTON 98115

210

OFFICIAL BUSINESS 